\title{
Superior mesenteric artery syndrome and the 'nutcracker phenomenon'
}

\author{
Paul Vulliamy, ${ }^{1}$ Vimal Hariharan, ${ }^{1}$ Jacques Gutmann, ${ }^{2}$ Dipankar Mukherjee ${ }^{1}$
}

${ }^{1}$ Department of General Surgery, Queen's Hospital, Romford, UK

${ }^{2}$ Department of Radiology, Queen's Hospital, Romford, UK

\section{Correspondence to}

Paul Vulliamy,

paul.vulliamy@gmail.com
To cite: Vulliamy $P$, Hariharan V, Gutmann J, et al. BMJ Case Rep Published online: [please include Day Month Year doi:10.1136/bcr-2013008734

\section{DESCRIPTION}

A 55 -year-old man presented with a 1-day history of vomiting, epigastric pain and bloating. $\mathrm{He}$ reported a weight loss of 3 stone over the last year through dieting, leaving him with a body mass index of 17. An abdominal examination revealed upper abdominal tenderness and distension. Blood tests showed a white cell count of $14.9 \times 10^{9} / 1$ but no other abnormalities.

An abdominal CT scan showed massive gastric and proximal duodenal dilation (figure 1), with compression of the duodenal lumen between the aorta and the superior mesenteric artery (SMA) (figure 2). The left renal vein was also compressed by the SMA close to its origin (figure 3), resulting in a left-sided varicocoele. On further questioning, the patient denied experiencing haematuria. Gastroduodenoscopy did not identify any intrinsic obstruction.

SMA syndrome, or aortomesenteric compression, occurs when an abnormally acute angle is formed between the abdominal aorta and the SMA, causing an extrinsic compression of the third part of the duodenum. ${ }^{1}$ As in this case, the condition most commonly affects underweight individuals with a history of rapid weight loss. It is characterised by clinical features of high gastrointestinal tract obstruction in the absence of any intrinsic blockage on endoscopy. The treatment involves nutritional

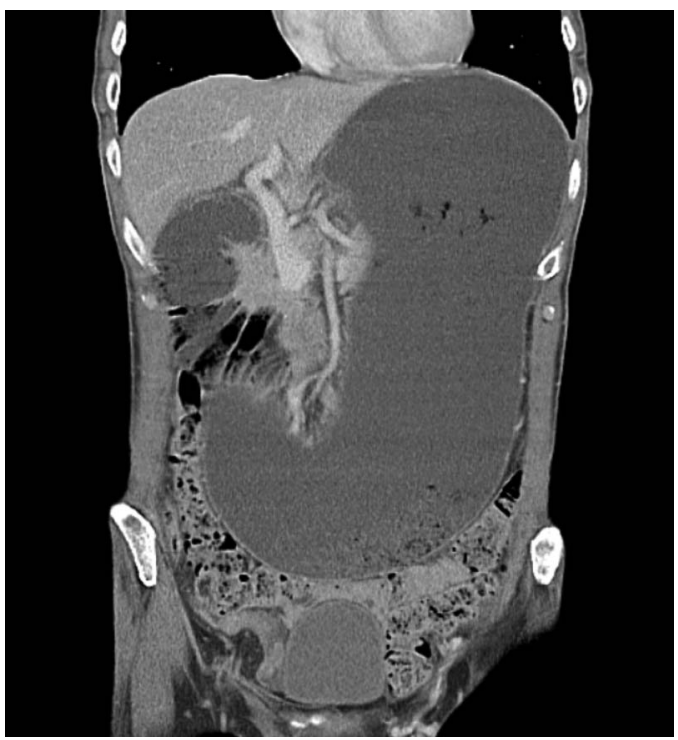

Figure 1 Sagittal CT scan showing massive dilation of the stomach and proximal duodenum.

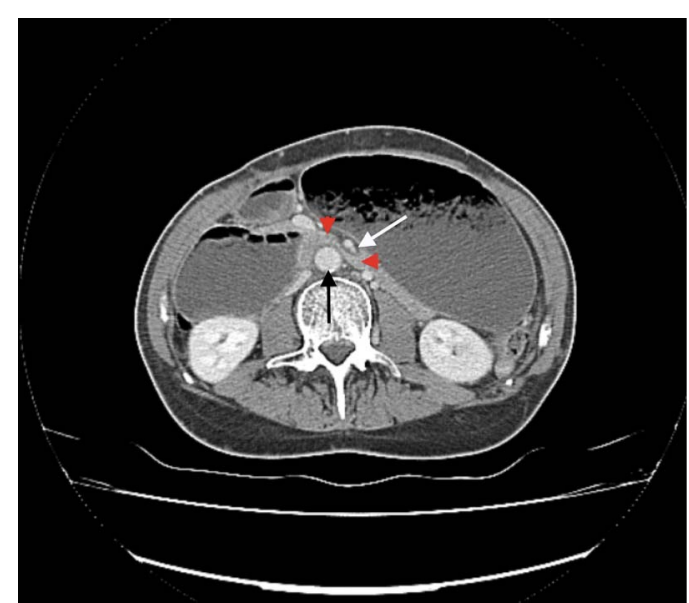

Figure 2 Axial CT section demonstrating duodenal compression (red arrows) between the abdominal aorta (black arrow) and superior mesenteric artery (white arrow).

support and surgery, in the form of duodenojejunostomy, if required.

The 'nutcracker phenomenon' describes compression of the left renal vein between the aorta and the SMA at its origin. Affected patients may be asymptomatic or experience haematuria and pain; a left-sided varicocoele may also be present. $^{2}$ Conservative management is often sufficient, but endovascular stenting is the treatment of choice if required.

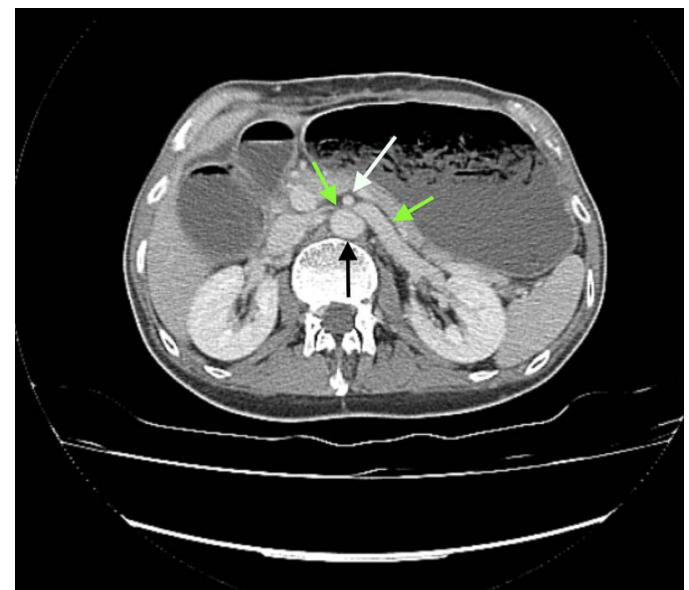

Figure 3 Axial CT section showing proximal dilatation and compression of the left renal vein (green arrows) between the abdominal aorta (black arrow) and superior mesenteric artery (white arrow). 


\section{Learning points}

- Superior mesenteric artery syndrome is an uncommon cause of high gastrointestinal tract obstruction, and should be suspected when endoscopic examination does not reveal an intrinsic obstruction.

- The 'nutcracker syndrome' should be considered as an uncommon cause of haematuria, particularly when a left sided varicocoele is also present.
Competing interests None.

Patient consent Obtained.

Provenance and peer review Not commissioned; externally peer reviewed.

\section{REFERENCES}

1 Ahmed AR, Taylor I. Superior mesenteric artery syndrome. Postgrad Med J 1997:73:776-8.

2 Kurklinsky AK, Rooke TW. Nutcracker phenomenon and nutcracker syndrome. Mayo Clin Proc 2010;85:552-9.

Copyright 2013 BMJ Publishing Group. All rights reserved. For permission to reuse any of this content visit http://group.bmj.com/group/rights-licensing/permissions.

BMJ Case Report Fellows may re-use this article for personal use and teaching without any further permission.

Become a Fellow of BMJ Case Reports today and you can:

- Submit as many cases as you like

- Enjoy fast sympathetic peer review and rapid publication of accepted articles

- Access all the published articles

- Re-use any of the published material for personal use and teaching without further permission

For information on Institutional Fellowships contact consortiasales@bmjgroup.com

Visit casereports.bmj.com for more articles like this and to become a Fellow 